\title{
Soil bacterial community structure remains stable over a 5-year chronosequence of insect-induced tree mortality
}

\section{Scott Ferrenberg ${ }^{*}$, Joseph E. Knelman ${ }^{1,2}$, Jennifer M. Jones ${ }^{3}$, Stower C. Beals $^{1,2}$, William D. Bowman ${ }^{1,2}$ and Diana R. Nemergut ${ }^{2,4}$}

${ }^{1}$ Department of Ecology and Evolutionary Biology, University of Colorado, Boulder, CO, USA

2 Institute of Arctic and Alpine Research, University of Colorado, Boulder, CO, USA

${ }^{3}$ Department of Plant Biology, University of Illinois, Urbana, IL, USA

${ }^{4}$ Department of Biology, Duke University, Durham, NC, USA

Edited by:

Jay T. Lennon, Indiana University, USA

\section{Reviewed by:}

Jay T. Lennon, Indiana University, USA

Kristen M. DeAngelis, University of

Massachusetts, USA

\section{*Correspondence:}

Scott Ferrenberg, Department of

Ecology and Evolutionary Biology,

University of Colorado, UCB 334

Boulder, CO 80309, USA

e-mail: scott.ferrenberg@colorado.edu
Extensive tree mortality from insect epidemics has raised concern over possible effects on soil biogeochemical processes. Yet despite the importance of microbes in nutrient cycling, how soil bacterial communities respond to insect-induced tree mortality is largely unknown. We examined soil bacterial community structure (via 16S rRNA gene pyrosequencing) and community assembly processes (via null deviation analysis) along a 5-year chronosequence (substituting space for time) of bark beetle-induced tree mortality in the southern Rocky Mountains, USA. We also measured microbial biomass and soil chemistry, and used in situ experiments to assess inorganic nitrogen mineralization rates. We found that bacterial community structure and assembly-which was strongly influenced by stochastic processes-were largely unaffected by tree mortality despite increased soil ammonium $\left(\mathrm{NH}_{4}^{+}\right)$pools and reductions in soil nitrate $\left(\mathrm{NO}_{3}^{-}\right)$pools and net nitrogen mineralization rates after tree mortality. Linear models suggested that microbial biomass and bacterial phylogenetic diversity are significantly correlated with nitrogen mineralization rates of this forested ecosystem. However, given the overall resistance of the bacterial community to disturbance from tree mortality, soil nitrogen processes likely remained relatively stable following tree mortality when considered at larger spatial and longer temporal scales-a supposition supported by the majority of available studies regarding biogeochemical effects of bark beetle infestations in this region. Our results suggest that soil bacterial community resistance to disturbance helps to explain the relatively weak effects of insect-induced tree mortality on soil $\mathrm{N}$ and $\mathrm{C}$ pools reported across the Rocky Mountains, USA.

Keywords: 16S rRNA gene pyrosequencing, biogeochemistry, community assembly, disturbance ecology, resistance, soil microbial community, soil processes

\section{INTRODUCTION}

Bark beetles (Curculionidae: Scolytinae) have killed billions of coniferous trees across North America and Europe in recent epidemics (Meddens et al., 2012; Kärvemo et al., 2014; Latifi et al., 2014). Extensive tree mortality following various types of forest disturbance has been linked to long-lasting changes in terrestrial biogeochemical cycles (Turner, 2010). Bark beetle-induced tree mortality can affect soil properties in a number of ways, with several of the more commonly reported pathways including: (1) the addition of large quantities of nitrogen $(\mathrm{N})$ to the forest floor in dropping needles (Morehouse et al., 2008; Griffin et al., 2011); (2) rapid cessation of root exudates leading to decreased concentration of carbon (C) substrates in soils under dead and dying trees (Xiong et al., 2011); and (3) increased soil moisture and inorganic $\mathrm{N}$ concentration as trees cease transpiration and $\mathrm{N}$ uptake, respectively (Morehouse etal., 2008; Griffin etal., 2011; Xiong et al., 2011). These biogeochemical changes can enhance mineralization rates, increasing the potential for losses of soil $\mathrm{C}$ and $\mathrm{N}$ from the system (Turner, 2010; Hicke et al., 2012; Moore et al., 2013; Campbell etal., 2014). Thus, concern over possible impacts of bark beetle-induced tree mortality on terrestrial $\mathrm{C}$ and $\mathrm{N}$ pools has motivated a number of recent biogeochemical models and studies (e.g., Kurz et al., 2008; Morehouse et al., 2008; Xiong et al., 2011; Edburg et al., 2012; Griffin and Turner, 2012; Moore et al., 2013; Rhoades et al., 2013). Yet, despite the primary roles of microbes in biogeochemical processes, how soil microbial community structure is affected by extensive insect-induced tree mortality remains poorly understood (Štursová et al., 2014).

Microbial community structure can have important influences on ecosystem processes (Monson etal., 2006; Reed and Martiny, 2007; Van der Heijden et al., 2008; Strickland et al., 2009), with shifts in community structure potentially altering ecosystem functioning (Schimel and Gulledge, 1998; Fraterrigo et al., 2006; Schimel and Schaeffer, 2012; Philippot et al., 2013). Meta-analyses of disturbance effects on microbial communities have found they are sensitive to a range of disturbance types, although generalizations may be difficult to make because of publication bias against negative results (Allison and Martiny, 2008; Griffiths and Philippot, 2012; Shade et al., 2012). Also, a shift in both the structure and function of soil fungal communities due to tree mortality from the 
European spruce bark beetle, Ips typographus, has been reported (Štursová et al., 2014). Taken collectively, these results suggest that changes in the structure of soil bacterial communities are a likely outcome of extensive tree mortality during bark beetle epidemics across the USA.

Given reported changes in soil chemistry following bark beetle infestations (Morehouse et al., 2008; Clow et al., 2011; Xiong et al., 2011; Griffin and Turner, 2012; Keville et al., 2013), bark beetle-induced tree mortality might alter the structure of soil bacterial communities via environmental filtering. Alternatively, stronger relative influences of stochastic processes in the assembly of soil bacterial communities have been noted following disturbance (Ferrenberg etal., 2013). An increased influence of stochastic processes could decouple microbial community responses from documented changes in soil chemistry while still leading to shifts in community structure via dispersal, ecological drift or historical contingencies (Nemergut et al., 2013). To understand how tree mortality during bark beetle epidemics affects soil bacterial communities in relation to soil properties and $\mathrm{N}$ cycling, we examined bacterial community structure and community assembly processes along a 5-year chronosequence of infestation by the mountain pine beetle (Dendroctonus ponderosae). The chronosequence included living control trees (year zero) and trees killed by mountain pine beetles one to 4 years prior to our study (years one-four of the chronosequence). In addition to characterizing bacterial communities, we also measured soil chemical properties of all samples, and completed experimental assessments of $\mathrm{N}$ mineralization via in situ incubations with soils from a subset of samples in each year of the chronosequence. We tested three primary hypotheses: (1) tree mortality caused a shift in bacterial community structure; (2) the relative influence of stochastic vs. deterministic processes on bacterial community assembly changed over time following tree mortality; and (3) tree mortality led to increased soil $\mathrm{N}$ concentrations and $\mathrm{N}$ mineralization rates. Finally, we used statistical models to examine the relationships between edaphic factors, soil bacterial community structure and soil processes across the temporal disturbance gradient presented by the chronosequence.

\section{MATERIALS AND METHODS STUDY SITE AND SOILS COLLECTION}

Our study was performed on soils from a mature pine forest at the University of Colorado's Mountain Research Station, $2900 \mathrm{~m}$ above sea level and approximately $11 \mathrm{~km}$ east of the Continental Divide in CO, USA $\left(40^{\circ} \mathrm{N} ; 105^{\circ} \mathrm{W}\right)$. The climate and soils of the area were described by Xiong et al. (2011), Mitton and Ferrenberg (2012), and Duhl et al. (2013), and factors underlying bark beetleinduced tree mortality in the site were described by Ferrenberg and Mitton (2014) and Ferrenberg et al. (2014). Work by Monson et al. (2006) and Weintraub et al. (2007) found soil microbial activity in nearby field sites to be greatest under snowpack during spring months. Thus we completed soil sampling in March of 2011, prior to snow melt. Previous work in nearby conifer forests does not indicate the presence of strong, small-scale spatial structuring of soil bacterial communities suggesting minor influences of community autocorrelation within this system (e.g., Ferrenberg et al.,
2013). Nevertheless, we selected trees that were scattered across a 2.5 hectare site with an attempt to maximize the distance among trees. All sampled trees were separated by a minimum of $3.5 \mathrm{~m}$ and a maximum of $150 \mathrm{~m}$.

All trees used in our study had uniquely numbered tags linking them to a forest demography study (see Ferrenberg et al., 2014) that established dates of bark beetle attack and subsequent tree mortality. Tree mortality from bark beetles occurs within a few weeks of mass attack and can be determined from notable changes in needle color (green fades to yellow and red), but does not cause substantial needle drop until the following year (Figure 1). We used trees from five temporal categories of bark beetle-induced mortality, which were considered as years $0,1,2,3$, and 4 of our 5 year chronosequence. Year 0 corresponded to samples collected from under living trees that were never attacked by bark beetles (we considered these samples as controls), while years 1 through 4 represented samples collected from under trees killed by bark beetles 1-4 years prior to sampling. Over a two day period, we collected a total of 50 soil samples $(N=50)$ which were equally partitioned ( 10 samples in each) across the 5 years of the chronosequence. Each soil sample was a composite of three, $130.5 \mathrm{~cm}^{3}$ cores from the top $5 \mathrm{~cm}$ of mineral soil (with all litter and visible organic materials removed) collected roughly $1 \mathrm{~m}$ from the base of mature limber pines (Pinus flexilis, see Ferrenberg and Mitton (2014) for range and life history descriptions). Following field extraction, all samples were transported on ice, sieved through $2 \mathrm{~mm}$ mesh, and a $10 \mathrm{~g}$ portion was stored at $-80^{\circ} \mathrm{C}$ for DNA extraction and the remainder at $4^{\circ} \mathrm{C}$ for biogeochemical analyses. Soils were resampled in June-July 2011 under 25 of the original 50 trees, with five samples from each year of the mortality chronosequence $(N=25)$ used for in situ experiments of $\mathrm{N}$ mineralization rates and nitrate pools as described below.

\section{DNA EXTRACTION, PYROSEQUENCING, AND SEQUENCE ANALYSIS}

Deoxyribonucleic acid was isolated using the MO BIO Power Soil DNA Extraction kit (MO BIO Laboratories, Carlsbad, CA, USA), and a fragment of the 16S rRNA gene encoding the V1-V2 region was amplified using the primers and PCR steps and program described in Nemergut et al. (2010), Knelman et al. (2012), and Ferrenberg et al. (2013). Three replicate PCR products were quantified, pooled and cleaned using MO BIO UltraClean-htp PCR Clean-up kits and 16S rRNA gene amplicons were sent to the Environmental Genomics Core Facility (Engencore) at University of South Carolina for 454 Life Sciences GS FLX Titanium pyrosequencing.

Pyrosequencing data were screened with the QIIME (Quantitative Insights Into Microbial Ecology) toolkit (Caporaso et al., 2010 ) with quality score $>25$, sequence length $>200$, and $<400$, maximum homopolymer of 6, 0 maximum ambiguous bases, and 0 mismatched bases in the primer. OTUs (Operational Taxonomic Units) were denoised using Denoiser (Reeder and Knight, 2010) and were picked at the 97\% identity level using UPARSE (OTU clustering pipeline; Edgar, 2013). The taxonomic identity of OTUs was assigned using RDP Classifier 2.2 (Wang et al., 2007) with the Greengenes core reference set (DeSantis et al., 2006) in QIIME. Samples were rarefied by randomly subsampling OTUs in QIIME 


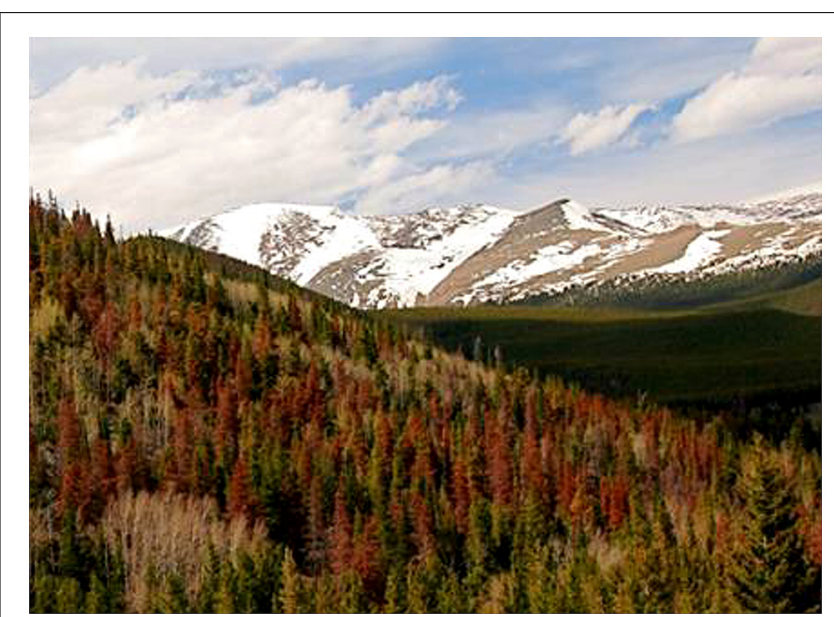

FIGURE 1 | A recent epidemic of the mountain pine beetle (Dendroctonus ponderosae) has led to the deaths of billions of pine trees across western North America. Rapid warming has allowed the beetle to expand its elevational and latitudinal ranges. This photo shows trees that were attacked 100s of meters above the beetles' historical elevational range limits in CO, USA. The trees with red needles were attacked during the previous growing season; recently attacked trees have not yet begun to fade (photo by Jeffry B. Mitton).

so that each library contained 1100 sequences (the fewest found in a single sample). Quality sequence data were not obtained from one sample in year four of the mortality chronosequence which was excluded from all community analyses. QIIME was also used to generate a UniFrac distance matrix (Lozupone and Knight, 2005) and measures of phylogenetic diversity (PD; Faith, 1992). Sequences and mapping data are available from figshare (Knelman, 2014a,b).

\section{SOIL ANALYSES}

Soil moisture, $\mathrm{pH}$, total \% , and $\% \mathrm{~N}, \mathrm{C}: \mathrm{N}$ ratio, $\mathrm{NH}_{4}^{+}$, dissolved organic carbon (DOC), and microbial biomass were quantified for all 50 samples. Soil moisture was determined with the gravimetric method after drying soils at $60^{\circ} \mathrm{C}$ for $48 \mathrm{~h}$. Soil $\mathrm{pH}$ was measured from a 1:5 ratio of soil to distilled and de-ionized $\mathrm{H}_{2} \mathrm{O}$, and total $\mathrm{C}$ and $\mathrm{N}$ determined using combustion as described by Knelman et al. (2012). Measures of $\mathrm{NH}_{4}^{+}$, DOC, and microbial biomass were determined via extractions from $10 \mathrm{~g}$ of soil with $0.5 \mathrm{M} \mathrm{K}_{2} \mathrm{SO}_{4}$ as described in Ferrenberg et al. (2013). $\mathrm{NH}_{4}^{+}$concentrations were determined using the sodium salicylate method and absorbance at $650 \mathrm{~nm}$ on a microplate reader (Mulvaney, 1996). DOC was determined using a TIC/TOC analyzer, with $\mathrm{DOC}=\mathrm{EC} / \mathrm{kEC}$ where $\mathrm{EC}=$ extractable $\mathrm{C}$ from soil and $\mathrm{kEC}=$ extractable $\mathrm{C}$ from microbial biomass which was estimated at 0.45 as in Beck et al. (1997). Microbial biomass C was calculated using the chloroform fumigation method (Brookes et al., 1985; Beck et al., 1997) with the procedures described in Ferrenberg et al. (2013). Soil chemistry data are available from figshare (Knelman, 2014b).

To evaluate the influence of tree death on $\mathrm{N}$ cycling, net $\mathrm{N}$ mineralization rates and concentrations of $\mathrm{NO}_{3}^{-}$in ion-exchange resin bags were measured in soils in June-July 2011. Nitrogen mineralization rates were assessed via in situ buried-bag incubation experiments. Soil cores $(3.5 \mathrm{~cm}$ diameter $\times 10 \mathrm{~cm}$ depth) were vertically split and sealed in plastic bags with one half returned to the mineral soil layer and covered with loose soil for 35 days, and the other half used for laboratory analysis to determine starting inorganic $\mathrm{N}$ concentrations using the procedures described in Bowman et al. (2006). Inorganic $\mathrm{N}$ leaching below the understory plant root zone of each sampled plot $(N=25)$ was measured using two ion-exchange resin bags (Binkley and Vitousek, 1989) inserted at a depth of $15 \mathrm{~cm}$ under undisturbed soils and left in place for 41 days prior to removal as described in Bowman et al. (2006). Bags were made of fine mesh nylon surrounded by a plastic cylinder to maintain their structure $\left(4.9 \mathrm{~cm}^{2} \times 2.5 \mathrm{~cm}\right.$ tall) and contained mixed-bed ion exchange resins (J. T. Baker, IONAC NM-60 H+ $\mathrm{H}^{+} \mathrm{OH}^{-}$; Phillipsburg, NJ, USA). $\mathrm{NH}_{4}^{+}-\mathrm{N}$ and $\mathrm{NO}_{3}^{-}-\mathrm{N}$ from the buried incubation and resin bags was extracted using $2 \mathrm{~mol} / \mathrm{L} \mathrm{KCl}$ and analyzed using a Lachat QuikChem 8000 Spectophotometric Flow Injection Analyzer and a Dionex DX 500 System IonPac AS11 Ion Chromatograph (Sunnyvale, CA, USA), respectively.

\section{DATA ANALYSES}

We compared community structure across years of the tree mortality chronosequence using multi-response permutation procedures (MRPP, a non-parametric method of comparing groups similar to PERMANOVA) and used non-metric multidimensional scaling (NMDS) to visualize the comparisons of community structure. Both MRPP and NMDS were completed on BrayCurtis distance matrices in PC-ORD (McCune and Mefford, 2011). After verifying that our data met test assumptions of normality via Shapiro-Wilk tests, we compared measures of $\alpha$-diversity (OTU richness, Pielou's evenness, and PD) using oneway ANOVA followed by Tukey's HSD means comparisons. To avoid violating assumptions of sample independence, we compared pairwise community $\beta$-diversity (Bray-Curtis dissimilarity) and pairwise UniFrac values using PERMANOVA followed by the permutation method of 'betadisper' in the vegan package for the R platform (R Development Core Team, 2011; Oksanen et al., 2013). Comparisons of soil chemistry from bacterial soil samples and from nitrogen resin bags and mineralization experiments were also performed via one-way ANOVA followed by Tukey's HSD means comparisons (Kruskal-Wallis test followed by Steel-Dwass means comparisons when test assumptions were not met).

We examined possible links between soil bacterial community structure and net $\mathrm{N}$ mineralization from incubation experiments (which were completed in situ using soils under five of the 10 trees in each year of our chronosequence, $N=25$ ) via multiple regression. We considered $\mathrm{N}$ mineralization values from all 25 samples as the dependent variable, and used stepwise fitting procedures to determine a best fit model using microbial biomass, bacterial OTU Shannon diversity $\left(\mathrm{H}^{\prime}\right)$, bacterial $\mathrm{PD}$, and soil environmental measures (soil moisture, soil temperature, $\mathrm{pH}, \% \mathrm{C}, \% \mathrm{~N}, \mathrm{C}: \mathrm{N}$ ratio, $\mathrm{DOC}, \mathrm{NH}_{4}^{+}$) as possible independent variables. The best fit model was selected via comparisons of Bayesian information criterion (BIC) values, with the lowest BIC score used to find the model that explained the 
most variation in $\mathrm{N}$ mineralization with the smallest number of retained factors (environmental and/or microbial). Independent variables retained in the best fit model were examined for collinearity via linear regressions, which revealed no significant relationships.

To assess possible correlations between individual environmental factors $\left(\% \mathrm{C}, \% \mathrm{~N}, \mathrm{C}: \mathrm{N}, \mathrm{NH}_{4}^{+}, \mathrm{DOC}, \mathrm{pH}\right.$, and soil moisture) and the soil bacterial community, we used Mantel tests to measure associations of the OTUs (determined at 97\% similarity) to each of the seven soil environmental variables (i.e., OTUs of each chronosequence year compared to each variable in an individual Mantel test). Mantel tests were completed using 5000 runs with Bray-Curtis distance matrices for bacterial communities and a Euclidean distance matrix for each environmental factor, with a Bonferonni sequential correction used to control for false discovery rate. Additionally, we used the null deviation approach of Chase and Myers (2011) to examine the assembly processes structuring bacterial communities. The null deviation method randomly assembles communities from the regional species pool (all OTUs found among samples) to assess how greatly the observed $\beta$-diversity patterns, based on presence-absence data of observed taxa, deviate from stochastic assembly. This approach disentangles the dissimilarity in community composition across samples from variation linked to changes in $\alpha$ - (local) and $\gamma$ - (regional) diversity (Chase and Myers, 2011). Controlling for changes in local diversity allows us to assess whether changes in $\beta$-diversity result from the relative influences of stochastic or deterministic processes. As in Ferrenberg et al. (2013), we calculated null deviation as the relative difference of the observed $\beta$ diversity from the null-model $\beta$-diversity, $\left(\beta_{\text {obs }}-\beta_{\text {null }}\right) / \beta_{\text {null }}$, with $\beta$-diversity measured as Sørenson-Czekanowski binary dissimilarity. Under the null model, expected $\beta$-diversity for each sample was calculated from 10000 stochastically assembled communities, and gamma diversity was calculated from the OTU (species) pools within all years of the tree mortality chronosequence. Because the community matrix used in the null devation model is in the form of presence-absence data, taxa with very low abundances
$(<0.5 \%$ of sequences per community) were removed before analyses to avoid the over-weighting of rare taxa (Ofițeru et al., 2010).

\section{RESULTS \\ BACTERIAL COMMUNITY STRUCTURE AND DIVERSITY}

Following rarefaction to an equal sequencing depth of 1100 , we found 3126 unique OTUs across all samples of our chronosequence (Table 1). There were an average of 1825 OTUs in bacterial communities of each year of the chronosequence, and 736 OTUs shared among all years. We found 124, 139, 160, 178, and 158 unique OTUs across years zero to four of the chronosequence, respectively.

We observed no significant difference in overall community structure among any years of the chronosequence (accessed via MRPP, Figure 2) or among proportional abundances of major phyla/subphyla (accessed via $\chi^{2}$ tests, Figure 3 ). Tree mortality caused a marginally significant increase in bacterial PD [KruskalWallis $\chi^{2}(4)=8.22, P=0.084$ ], but did not alter any additional measures of alpha $(\alpha)$ diversity [sample level OTU richness and Shannon diversity (Table 1)]. Tree mortality did not significantly influence measures of $\beta$-diversity (pairwise dissimilarity of samples) such as pairwise Bray-Curtis and UniFrac measures (Table 1).

\section{COMMUNITY STRUCTURE AND CORRELATIONS WITH ENVIRONMENT}

We found relatively few associations (3 out of 35 possible combinations) between bacterial community structure and soil chemistry/environmental variables across the tree mortality chronosequence when examined via Mantel tests. Specifically, we found the bacterial communities from the first year after tree mortality were significantly associated with soil moisture $(r=0.58$, $P=0.024)$ and $\mathrm{pH}(r=0.45, P=0.011)$; while communities from the second year after tree mortality were significantly associated with extractable ammonium $\left(\mathrm{NH}_{4}^{+}\right)$concentrations $(r=0.54$, $P=0.006)$.

Using the null deviation approach to assess community assembly processes (Chase and Myers, 2011), we assembled communities

\begin{tabular}{|c|c|c|c|c|c|c|}
\hline $\begin{array}{l}\text { Years since tree } \\
\text { mortality }\end{array}$ & $\begin{array}{l}\text { Biomass } \\
\text { (mg/g soil) }\end{array}$ & $\gamma$-diversity & $P D(\alpha)$ & Shannon $\mathbf{H}^{\prime}(\alpha)$ & $\begin{array}{l}\text { Bray-Curtis } \\
\text { dis. }(\beta)\end{array}$ & UniFrac $(\beta)$ \\
\hline 0 & $0.23( \pm 0.02)$ & 1763 & $46.3( \pm 1.07)$ & $8.7( \pm 0.10)$ & $0.67( \pm 0.01)$ & $0.23( \pm 0.010)$ \\
\hline 1 & $0.24( \pm 0.04)$ & 1808 & $47.3( \pm 1.40)$ & $8.7( \pm 0.12)$ & $0.68( \pm 0.01)$ & $0.24( \pm 0.005)$ \\
\hline 3 & $0.23( \pm 0.02)$ & 1923 & $48.1( \pm 0.95)$ & $8.9( \pm 0.10)$ & $0.68( \pm 0.01)$ & $0.22( \pm 0.012)$ \\
\hline 4 & $0.25( \pm 0.02)$ & 1773 & $50.7( \pm 0.56)$ & $8.9( \pm 0.10)$ & $0.69( \pm 0.01)$ & $0.24( \pm 0.017)$ \\
\hline$P$-value & $>0.10$ & - & 0.084 & $>0.10$ & $>0.10$ & $>0.10$ \\
\hline
\end{tabular}

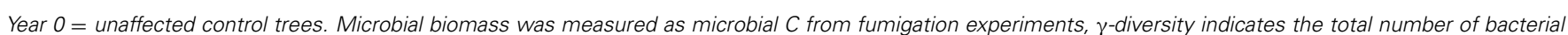

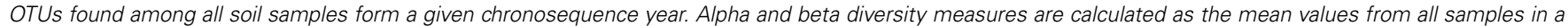

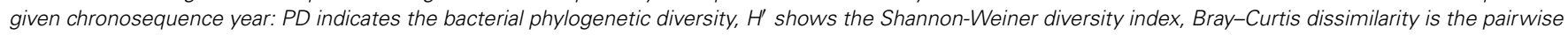
Bray-Curtis dissimilarity index, UniFrac values are weighted by species abundances. Values shown in the table are untransformed means ( \pm 1 SE). 

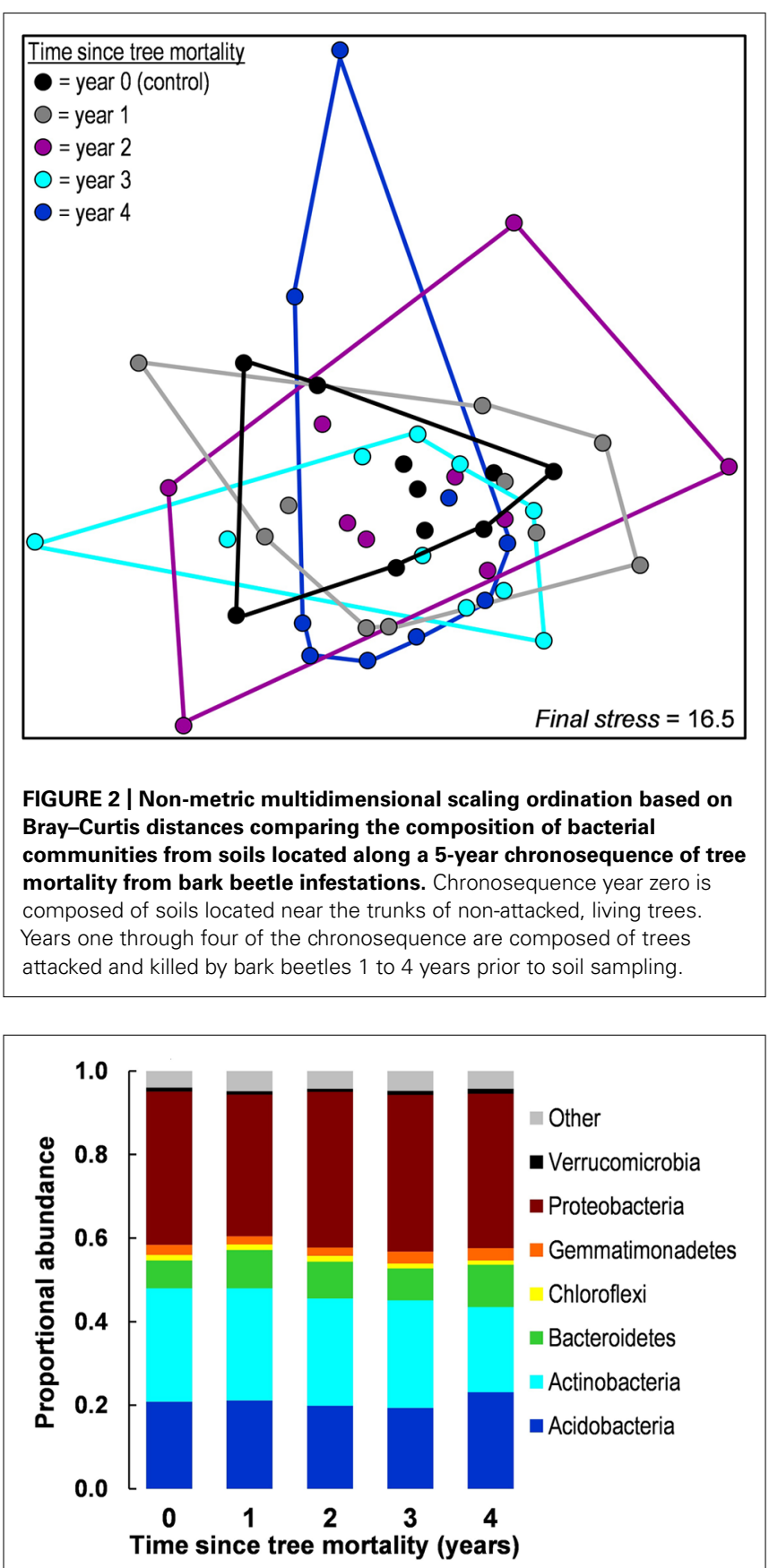

FIGURE 3 | Proportional abundances of bacterial phyla along a 5-year chronosequence of tree mortality from bark beetle infestations.

Candidate phyla (recently identified phylogentic groups awaiting further description) were grouped together as 'Other.'

in silico from the regional species pool to determine if the observed $\beta$-diversity patterns deviated from purely stochastic assembly. Null deviation values can range from zero to one, with values closer to zero indicating less deviation from random, suggesting a greater relative influence of stochastic processes. Alternatively, values closer to one $( \pm 1)$ are suggestive of greater deterministic structure, possibly due to niche-associations. We found that null

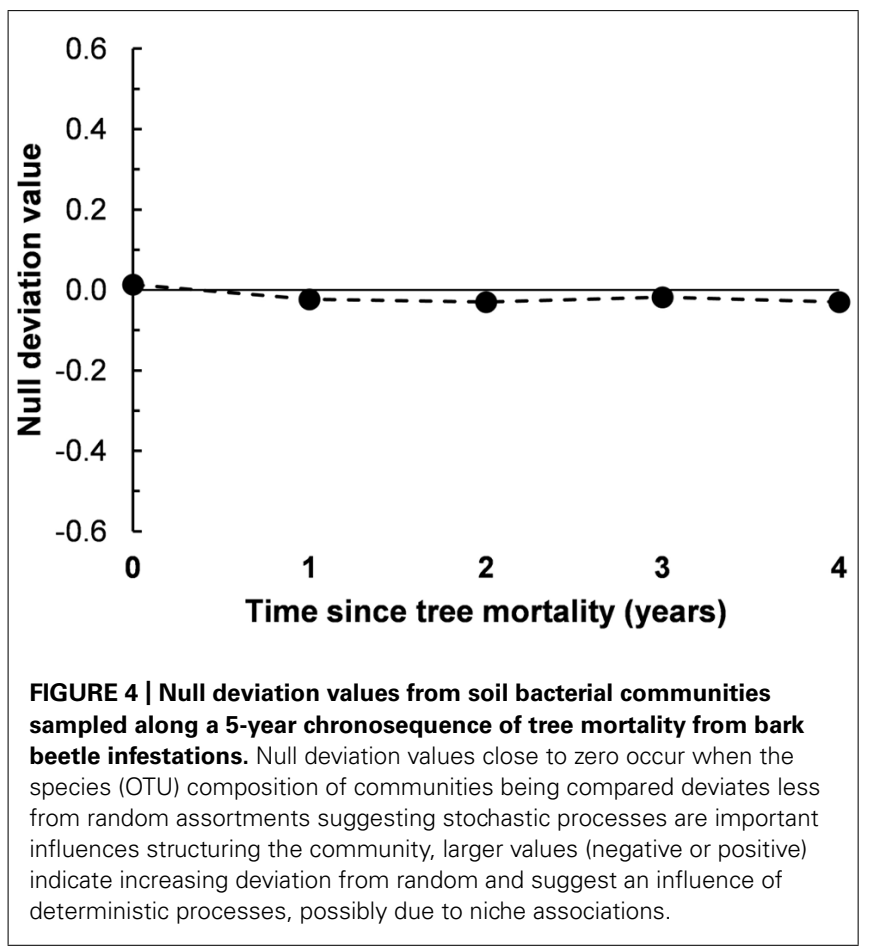

deviation values were very near zero across all 5 years of the bark beetle mortality chronosequence (Figure 4), ranging from 0.014 in bacterial communities from soils under live trees (chronosequence year 0 ) and increasing in absolute value to $-0.023,-0.030$, -0.018 , and -0.030 in years one through four after tree mortality, respectively (Figure 4). These increases in null deviation values indicate an increase in deterministic assembly after tree death, but the relatively low values suggest continued influences of stochastic processes on bacterial assemblages over time after tree mortality (Figure 4).

\section{SOIL CHEMISTRY AND N MINERALIZATION/RESIN BAG EXPERIMENTS}

Tree mortality led to a significant, twofold increase in extractable $\mathrm{NH}_{4}^{+}$between living control trees (year 0 of the chronosequence) and year two after bark beetle attack $[F(4,45)=3.35, P=0.018$; Figure 5]. By year three of the chronosequence, $\mathrm{NH}_{4}^{+}$had returned to levels similar to those in soils under living control trees (year 0 ). Total soil $\mathrm{N}$ decreased in the first year after tree mortality, but similar to $\mathrm{NH}_{4}^{+}$, reached its highest levels with a (marginally significant) $40 \%$ increase by the second year after tree mortality $[F(4,45)=2.37, P=0.066$; Figure 5]. By the fourth year after tree mortality, total $\mathrm{N}$ had returned to a level equivalent to that found in soils under living control trees (Figure 5). Total soil C and DOC also increased to peak levels by the second year after tree mortality, but this increase was not significant (Table 2) due to high intra-annual variation. Percent soil moisture increased steadily, but not significantly, over time following tree mortality from $4.4 \%$ in unaffected soils to $6.4 \%$ by the fourth year after trees died (Table 2). Similarly, soil $\mathrm{pH}$ (mean $\mathrm{pH}=6.4$ across the chronosequence) was not significantly affected (Table 2 ) by tree mortality. 

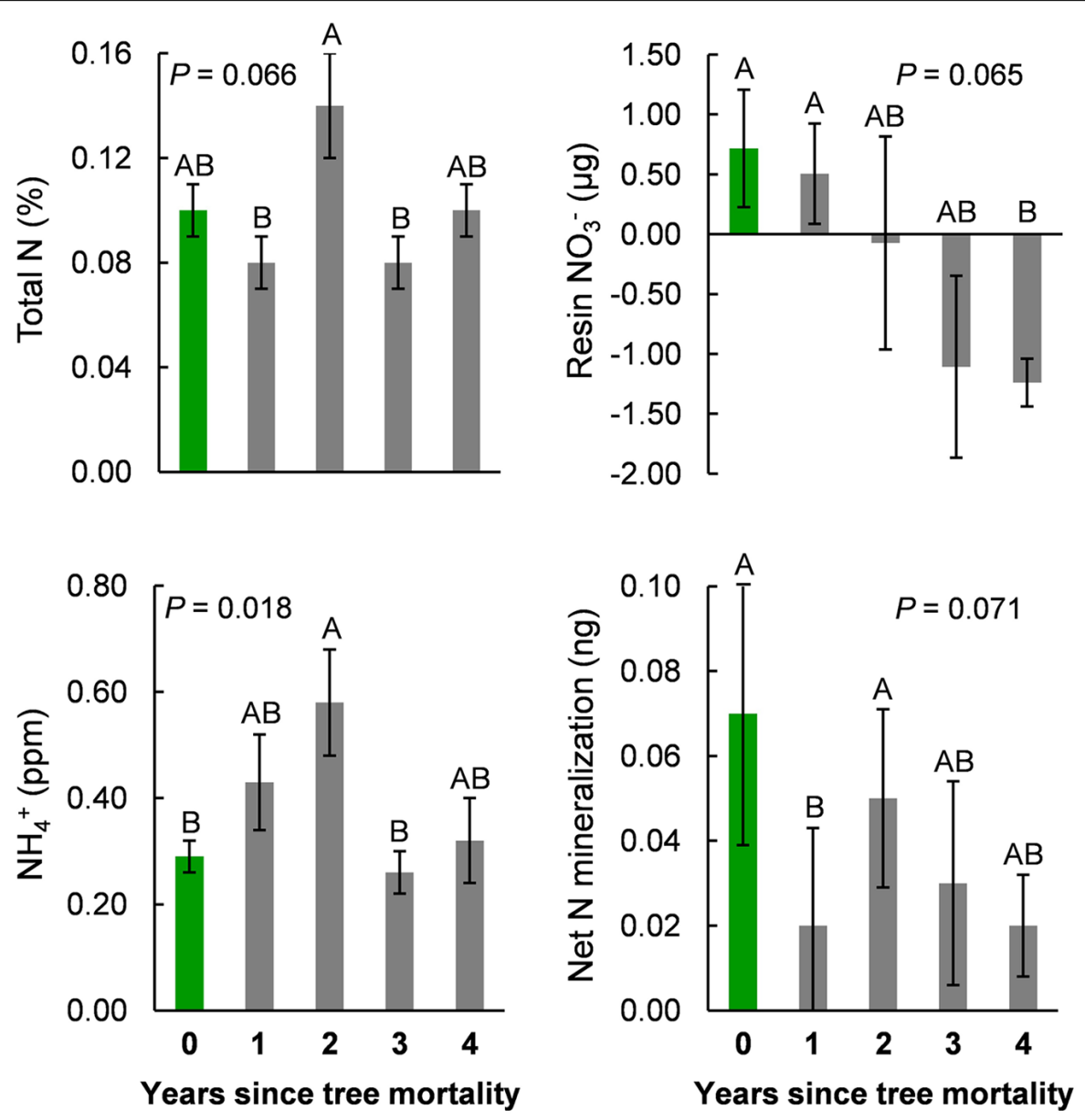

FIGURE 5 | Measures of total soil $\mathbf{N}$ (upper-left), ammonium $\left(\mathrm{NH}_{4}^{+}\right.$, lower-left), plant available nitrogen $\left(\mathrm{NO}_{3}^{-}\right.$measured from ion-exchange resin bags, upper-right), and net nitrogen mineralization from in situ incubation experiments (lower-right) across a 5-year chronosequence of bark beetle-induced tree

mortality. Year zero (0, green bars) represents samples collected under live trees that were not attacked by bark beetles during the study. All other samples were collected from under trees attacked and killed by bark beetles one to four (1-4, gray bars) years prior to field sampling.

We found a $272 \%$ decrease in plant available $\mathrm{N}$ (resin bag $\mathrm{NO}_{3}^{-}$) from control soils under living trees (year 0) to the last year (year 4) of our chronosequence following tree mortality, which, due to high variability was a marginally significant change [KruskalWallis $\chi^{2}(4)=8.83, P=0.065$ ] (Figure 5). Net $\mathrm{N}$ mineralization rates declined by $115 \%$ in the first year after tree mortality [also marginally significant due to variation within years; KruskalWallis $\chi^{2}(4)=8.61, P=0.071$; Figure 5], but returned to levels similar to those found in control soils by the second year after tree mortality.

\section{N-MINERALIZATION AND BACTERIAL/ENVIRONMENTAL FACTORS}

Using stepwise regression we identified best fit models linking bacterial PD, microbial biomass, and soil environmental measures as independent variables and net $\mathrm{N}$ mineralization as the dependent variable. The model with the overall best fit (accessed via BIC score) did not retain any environmental measures (Table 3), but did retain PD $(P=0.47)$, microbial biomass $(P=0.044)$ and the interaction of $\mathrm{PD} \times$ microbial biomass $(P=0.025)$ as

significantly associated with net $\mathrm{N}$ mineralization rates $\left(R^{2}=0.31\right.$, Table 3).

\section{DISCUSSION}

We investigated the effects of insect-induced tree mortality on soil bacterial community structure and assembly, and on soil $\mathrm{N}$ biogeochemical processes using a 5-year chronosequence of mountain pine beetle (Dendroctonus ponderosae) infestations in the southern Rocky Mountains, CO, USA - a region that has experienced an unprecedented level of tree mortality during recent bark beetle epidemics (Meddens et al., 2012). Counter to our hypothesized shifts in bacterial community structure, we found only moderate increases in bacterial phylogenetic diversity (PD, Table 1) over time following tree mortality, and no significant changes in microbial biomass, OTU Shannon diversity $\left(\mathrm{H}^{\prime}\right)$, pairwise community dissimilarity (i.e., Bray-Curtis dissimilarity and pairwise UniFrac distance), and overall community structure (Figures 2 and 3 ). While we found few associations among soil environmental properties and bacterial community structure, Mantel tests revealed 


\begin{tabular}{|c|c|c|c|c|}
\hline $\begin{array}{l}\text { Years } \\
\text { since tree } \\
\text { mortality }\end{array}$ & Moisture (\%) & DOC (mg/g soil) & Total C (\%) & pH \\
\hline 0 & $4.4 \quad( \pm 0.5)$ & $0.06 \quad( \pm 0.01)$ & $2.42 \quad( \pm 0.25)$ & $6.3( \pm 0.1)$ \\
\hline 1 & $4.7 \quad( \pm 1.1)$ & $0.08 \quad( \pm 0.02)$ & $2.21 \quad( \pm 0.30)$ & $6.5( \pm 0.1)$ \\
\hline 2 & $5.2( \pm 0.9)$ & $0.11 \quad( \pm 0.03)$ & $3.24 \quad( \pm 0.56)$ & $6.3( \pm 0.1)$ \\
\hline 3 & $6.4 \quad( \pm 1.1)$ & $0.06 \quad( \pm 0.01)$ & $2.04 \quad( \pm 0.20)$ & $6.6( \pm 0.1)$ \\
\hline 4 & $6.4 \quad( \pm 1.4)$ & $0.07 \quad( \pm 0.01)$ & $2.48 \quad( \pm 0.29)$ & $6.4( \pm 0.1)$ \\
\hline$P$-value & $>0.10$ & 0.082 & $>0.10$ & $>0.10$ \\
\hline
\end{tabular}

${ }^{\dagger}$ Year $0=$ unattacked control trees. P-values are from one-way ANOVA on log transformed data; all values are presented as untransformed means \pm 1 SE. Soil moisture was determined from gravimetric dry-down methods, DOC, dissolved organic carbon.

significant relationships among community structure and soil moisture and $\mathrm{pH}$ in the first year after tree mortality, and community structure and ammonium $\left(\mathrm{NH}_{4}^{+}\right)$in the second year after tree mortality. Null deviation values also indicated that tree mortality led to a minor increase in deterministic influences on community structure, but overall, stochastic processes seemingly remained important for bacterial communities across the chronosequence (Figure 4).

Soil properties such as $\mathrm{pH}$, moisture, and $\mathrm{C}$ and $\mathrm{N}$ concentrations are known to influence soil microbial diversity and activity at both local and global scales (Fierer and Jackson, 2006; Gundersen et al., 2006; Curiel Yuste et al., 2007; Reed and Martiny, 2007; Strickland et al., 2009; Philippot et al., 2013; Landesman et al., 2014). Tree mortality can alter these soil properties as litter inputs and root deposition from mature trees often influence local to regional edaphic factors (Finzi et al., 1998; Chapman etal., 2006; Ushio et al., 2008, 2010; Thoms et al., 2010; Weber and Bardgett, 2011), and both spatial and temporal patterns of microbial diversity have been linked to gradients in tree physiology, litter chemistry, dominant species cover, and canopy

Table 3 | Best fit model linking soil microbial biomass and bacterial phylogenetic diversity to net nitrogen mineralization across a chronosequence of tree mortality.

\begin{tabular}{lll}
\hline Predictor variables $^{\dagger}$ & $\boldsymbol{F}$ & $\boldsymbol{P}$ \\
\hline PD $\times$ microbial biomass & 5.94 & 0.025 \\
Microbial biomass (mg/g soil) & 3.70 & 0.044 \\
Phylogenetic diversity (PD) & 3.62 & 0.047 \\
\hline
\end{tabular}

Model $R^{2}=0.31, B / C=-39.6$

${ }^{\dagger}$ Predictor variables were selected via stepwise multiple-regression with smallest BIC (Bayesian information criterion) determing the best model. In addition to microbial variables, starting possible factors included $\% \mathrm{~N}, \% \mathrm{C}, \mathrm{DOC}, \mathrm{C}: \mathrm{N}, \mathrm{pH}$, soil moisture, and soil temperature. tree mortality (Ushio et al., 2008; Thoms et al., 2010; Weber and Bardgett, 2011; Landesman et al., 2014; Štursová et al., 2014). The greater deterministic influences on community assembly in the first year after tree mortality (Figure 4), along with the association of bacterial community structure with soil moisture, $\mathrm{pH}$, and $\mathrm{NH}_{4}^{+}$in the first and second years after tree mortality coincided with the largest changes in soil chemical properties along the mortality chronosequence (Table 2; Figure 5). Specifically, tree mortality was followed by a significant increase $(P<0.05)$ in ammonium $\left(\mathrm{NH}_{4}^{+}\right)$and a moderate increase $(P<0.10)$ in both total $\mathrm{N}$ concentration $(\% \mathrm{~N})$ and $\mathrm{DOC}$, and a nonsignificant but notable increase in total $\mathrm{C}$ concentration $(\% \mathrm{C})$ with all of these measures peaking in the second year after tree mortality.

While tree mortality in other coniferous forest ecosystems has been linked to large changes in soil microbial biomass and community structure (Högberg et al., 2007; Štursová et al., 2014), we found relatively muted effects of tree death on microbial community measures by comparison. A possible explanation is that tree mortality in our study system had little impact on key soil chemical and physical properties known to influence microbial communities in forested ecosystems (Högberg and Högberg, 2002; Monson et al., 2006; Högberg et al., 2007; Weintraub et al., 2007). However, other studies of tree mortality (from girdling experiments) completed $<1 \mathrm{~km}$ from our field sites also found moderate effects of tree death on microbial biomass and enzyme activity despite significant changes in soil $\mathrm{N}$ concentrations and DOC (Weintraub et al., 2007) and weaker than expected effects on soil processes governed by microbes (Moore et al., 2013). So while it is likely that tree mortality has smaller impacts on soil microbial communities and ecosystem processes in this study system compared to others, the stability of community structure in the face of variable $\mathrm{N}$ pools found here and by others suggests a general resistance of soil microbial communities to disturbance of the forest canopy.

Disturbances have long been known to influence species diversity and abundance patterns in macro-biological communities and the majority of microbial communities studied to date have been sensitive to a range of disturbance types, severities, and durations (Allison and Martiny, 2008; Shade et al., 2012). Nevertheless, the structure of bacterial communities in our study resisted bark beetle-induced tree mortality despite concurrent changes in soil $\mathrm{N}$ pools and cycling processes (Table 1; Figure 5 ). The stability of communities in response to perturbation relies on the ability of individual bacteria to tolerate, endure, or adapt to environmental change. A range of life history strategies facilitate bacterial resistance to disturbance such as: periods of reduced metabolic activity or dormancy, rapid dispersal and colonization, stochastic gene expression, or high efficiency in resource use which is common to oligotrophic bacteria (Lennon and Jones, 2011; Shade et al., 2012; de Vries and Shade, 2013). Communities in our study system are marked by a comparatively high proportions of phyla that contain an abundance of gram-positive taxa (roughly 26\% across samples, Figure 3) which are often relatively slow growing (a traitcommon to oligotrophs) and also can use dormancy in order to survive disturbance events (Drenovsky et al., 2010; de Vries and Shade, 2013). Thus, the resistance of soil bacterial 
community structure to environmental changes linked to tree mortality from bark beetle infestations might be explained by the relatively large proportion of oligotrophic taxa found in our study system.

While environmental factors can have important influences on the assembly and structure of microbial communities, a growing body of evidence indicates that bacterial communites can also be strongly influenced by stochastic processes (Burke et al., 2011; Ferrenberg et al., 2013; Nemergut et al., 2013). Null deviation values across our sampling chronosequence suggest that stochastic processes have relatively strong influences on the bacterial communities of our study site, regardless of time since tree death. Even in chronosequence years with the higher null deviations, which would indicate stronger influences of deterministic processes, the values still remained lower than in bacterial communities of soils in a nearby conifer forest $(11 \mathrm{~km}$ east, $640 \mathrm{~m}$ lower in elevation) sampled 2 months prior to our study (see Ferrenberg et al., 2013). While environmental factors would still influence metabolic processes and tolerances in these stochastically assembled bacterial communities (Nemergut et al., 2013), stochastic influences likely lead to heterogeneous distributions of microbial life history traits which may reduce the effects of environmental change on community structure. At the same time, soil processes may remain more stable in the face of environmental changes in cases where microbes and their functional traits are stochastically dispersed and assembled across larger spatial and temporal scales (e.g., Burke et al., 2011). While this scenario has not been thoroughly investigated for soil microbial communities, a strong influence of heterogeneous distributions of vegetation species on the maintenance of ecosystem functioning following disturbances in coniferous forests has been observed (Chapin et al., 2002; Turner, 2010). In particular, vegetation heterogeneity before and after disturbances such as wildfires has been found to not only mediate temporal disturbance effects, but to also help maintain soil nutrients and processes such as $\mathrm{N}$ cycling (Turner et al., 2007).

Similar to other insect epidemics, bark beetle-induced tree mortality has been shown to increase concentrations of ammonium $\left(\mathrm{NH}_{4}^{+}\right)$, nitrate $\left(\mathrm{NO}_{3}^{-}\right)$, and in some cases, net mineralization rates in soil organic and mineral horizons (Clow et al., 2011; Xiong et al., 2011; Griffin and Turner, 2012; Keville et al., 2013). We found partial support for our third hypothesis that bark beetle-infestation in our study system would lead to increases in soil $\mathrm{N}$ pools and $\mathrm{N}$ mineralization rates. Specifically, we found increased concentrations of $\mathrm{NH}_{4}^{+}$, and decreased plant available $\mathrm{N}\left(\mathrm{NO}_{3}^{-}\right)$and net mineralization rates in mineral soils (Figure 5). While our results are lower in magnitude relative to some measures from other studies-possibly associated with low pools of $\mathrm{C}$ and $\mathrm{N}$ in our soils-there is overall agreement across studies that bark beetle-induced tree mortality moderately affects soil N. Previous studies have also found differences in $\mathrm{N}$ dynamics between organic and mineral soil horizons (Keville et al., 2013) and substantial site variation in net $\mathrm{N}$ mineralization rates (Griffin and Turner, 2012) suggesting a need to consider experimental context during interpretations. In particular, Schimel and Schaeffer (2012) hypothesized that microbial processes may be more controlled by physical features and structure in mineral soils than in organic layers (Schimel and Schaeffer, 2012), thereby shifting the relationship between structure and function among soil horizons.

Despite concern that extensive tree mortality from bark beetle epidemics would lead to substantial losses of $\mathrm{C}$ and $\mathrm{N}$ from impacted forests across western North America, reported effects have fallen short of predictions (Clow et al., 2011; Griffin et al., 2011; Griffin and Turner, 2012; Keville et al., 2013; Moore et al., 2013). This contradiction invokes a key role of soil microbial communities in ecosystem responses to tree mortality. Indeed, in the same ecosystem we studied, Moore etal. (2013) found that both photosynthesis and ecosystem respiration declined concurrently after tree death. While our measures of soil bacterial community structure were collected roughly 3 months prior to our $\mathrm{N}$ mineralization experiments and therefore must be conservatively interpreted, we found that bacterial PD and total microbial biomass were significantly correlated with $\mathrm{N}$ mineralization rates across the tree mortality chronosequence (Table 3 ). This indication that bacterial community structure is important for $\mathrm{N}$ mineralization processes in our forested study site agrees with work in other systems (Fraterrigo et al., 2006; Philippot et al., 2013). Nevertheless, the resistance to disturbance from tree mortality of the bacterial community of this subalpine conifer-forest likely reduces the effects of tree mortality on ecosystem processes and could help to explain the relatively weak effects of bark beetle-induced tree mortality on soil $\mathrm{N}$ pools. The influence of bacterial phylogenetic diversity on soil $\mathrm{N}$ processes also suggests an interesting hypothesis that spatial heterogeneity resulting from stochastic assembly in bacterial communities may play an important role in the stability of spatial and temporal processes rates.

\section{CONCLUSION}

Recent climatic changes have spurred a worldwide increase in insect-induced tree mortality, raising concern over possible effects on biogeochemical cycles (Wardle et al., 2004; Adams et al., 2010; Hicke et al., 2012). Despite being the primary drivers of terrestrial biogeochemical processes, the detailed responses of soil microbial communities to extensive tree mortality during insect epidemics have received limited study (Štursová et al., 2014). We found that soil bacterial communities resisted disturbance from bark beetleinduced tree mortality along a 5-year chronosequence, and that bacterial community assembly was largely influenced by stochastic processes. Results from our characterizations of soil chemistry and nitrogen mineralization agree with reports from similar forest ecosystems (Clow et al., 2011; Griffin et al., 2011; Griffin and Turner, 2012; Keville et al., 2013), as we found only short-lived, moderate effects of bark beetle-induced tree mortality on soil $\mathrm{N}$ pools and mineralization rates. The stochastic assembly of bacterial communities in this system likely promotes landscape heterogeneity of microbial functional traits, which coupled with stability of bacterial communities following tree death could help to explain the muted effects of tree mortality on soil $\mathrm{N}$ processes across larger spatial scales. Yet given the paucity of reports detailing resistance to disturbance in microbial communities, determining the community characteristics which confer greater resistance to disturbance (Shade et al., 2012) and the bacterial 
community compositional-traits that influence biogeochemical processes (Schimel and Schaeffer, 2012) will require additional study.

\section{ACKNOWLEDGMENTS}

This research was supported in part by the University of Colorado's Department of Ecology and Evolutionary Biology, the Niwot Ridge LTER grant NSF-DEB-1027341, REU site grant NSFDBI-1004115, and an award from the University of Colorado's Museum of Natural History to Scott Ferrenberg. We thank Sean O’Neill for invaluable laboratory assistance; Kelly Matheson, Max Barlerin, Taylor Robinson, and Akasha Faist for aiding with soil collections and Tim Seastedt for logistical support. Publication of this article was funded by the University of Colorado Boulder Libraries Open Access Fund.

\section{REFERENCES}

Adams, H. D., Macalady, A. K., Breshears, D. D., Allen, C. D., Stephenson, N. L., Saleska, S. R., etal. (2010). Climate-Induced tree mortality: earth system consequences. Eos 91, 153-154. doi: 10.1029/2010EO1 70003

Allison, S. D., and Martiny, J. B. H. (2008). Resistance, resilience, and redundancy in microbial communities. Proc. Natl. Acad. Sci. U.S.A. 105, 11512-11519. doi: 10.1073/pnas.0801925105

Beck, T., Joergensen, G., Kandeler, E., Makeschin, F., Nuss, E., Oberholzer, H. R., et al. (1997). An inter-laboratory comparison of ten different ways of measuring soil microbial biomass C. Soil Biol. Biochem. 29, 1023-1032. doi: 10.1016/S00380717(97)00030-8

Binkley, D., and Vitousek, P. M. (1989). “Soil nutrient availability," in Plant Physiological Ecology: Field Methods and Instrumentation, eds R. W. Pearcy, J. R. Ehleringer, H. A. Mooney, and P. W. Rundel (London: Chapman and Hall), 75-96.

Bowman, W. D., Gartner, J. R., Holland, K., and Wiedermann, M. (2006). Nitrogen critical loads for alpine vegetation and terrestrial ecosystem response: are we there yet? Ecol. Appl. 16, 1183-1193. doi: 10.1890/10510761(2006)016[1183:NCLFAV]2.0.CO;2

Brookes, P. C., Landman, A., Pruden, G., and Jenkinson, D. S. (1985). Chloroform fumigation and the release of soil nitrogen: a rapid direct extraction method to measure microbial biomass nitrogen in soil. Soil Biol. Biochem. 17, 837-842. doi: 10.1016/0038-0717(85)90144-0

Burke, C., Steinberg, P., Rusch, D., Kjelleberg, S., and Thomas, T. (2011). Bacterial community assembly based on functional genes rather than species. Proc. Natl. Acad. Sci. U.S.A. 108, 14288-14293. doi: 10.1073/pnas.1101591108

Campbell, J. L., Socci, A. M., and Templer, P. H. (2014). Increased nitrogen leaching following soil freezing is due to decreased root uptake in a northern hardwood forest. Glob. Change Biol. 20, 2663-2673. doi: 10.1111/gcb.12532

Caporaso, J. G., Kuczynski, J., Stombaugh, J., Bittinger, K., Bushman, F. D., Costello, E. K., et al. (2010). QIIME allows analysis of high-throughput community sequencing data. Nat. Methods 7, 335-336. doi: 10.1038/nmeth. f.303

Chapin, F. S. III, Matson, P. A., and Mooney H. A. (2002). Principles of Terrestrial Ecosystem Ecology. New York: Springer-Verlag.

Chapman, S. K., Langley, J. A., Hart, S. C., and Koch, G. W. (2006). Plants actively control nitrogen cycling: uncorking the microbial bottleneck. New Phytol. 169, 27-34. doi: 10.1111/j.1469-8137.2005.01571.x

Chase, J. M., and Myers, J. A. (2011). Disentangling the importance of ecological niches from stochastic processes across scales. Philos. Trans. R. Soc. Lond. Biol. 366, 2351-2363. doi: 10.1098/rstb.2011.0063

Clow, D. W., Rhoades, C., Briggs, J., Caldwell, M., and Lewis, W. M. Jr. (2011). Responses of soil and water chemistry to mountain pine beetle induced tree mortality in Grand County, Colorado, USA. Appl. Geochem. 26, S174-S178. doi: 10.1016/j.apgeochem.2011.03.096

Curiel Yuste, J., Baldocchi, D. D., Gershenson, A., Goldstein, A., Misson, L., and Wong, S. (2007). Microbial soil respiration and its dependency on carbon inputs, soil temperature and moisture. Glob. Change Biol. 13, 2018-2035. doi: 10.1111/j.1365-2486.2007.01415.x
DeSantis, T. Z., Hugenholtz, P., Larsen, N., Rojas, M., Brodie, E. L., Keller, K., et al. (2006). Greengenes, a chimera-checked 16S rRNA gene database and workbench compatible with ARB. Appl. Environ. Microb. 72, 5069-5072. doi: 10.1128/AEM.03006-05

de Vries, F. T., and Shade, A. (2013). Controls on soil microbial community stability under climate change. Front. Microb. 4:265. doi: 10.3389/fmicb.2013.00265

Drenovsky, R. E., Steenwerth, K. L., Jackson, L. E., and Scow, K. M. (2010). Land use and climatic factors structure regional patterns in soil microbial communities. Glob. Ecol. Biogeogr. 19, 27-39. doi: 10.1111/j.1466-8238.2009. 00486.x

Duhl, T. R., Gochis, D., Guenther, A., Ferrenberg, S., and Pendall, E. (2013). Emissions of BVOC from lodgepole pine in response to mountain pine beetle attack in high and low mortality forest stands. Biogeosciences 10, 483-499. doi: 10.5194/bg-10-483-2013

Edburg, S. L., Hicke, J. A., Brooks, P. D., Pendall, E. G., Ewers, B. E., Norton, U., et al. (2012). Cascading impacts of bark beetle-caused tree mortality on coupled biogeophysical and biogeochemical processes. Front. Ecol. Environ. 10:416-424. doi: $10.1890 / 110173$

Edgar, R. C. (2013). UPARSE: highly accurate OTU sequences from microbial amplicon reads. Nat. Methods 10, 996-998. doi: 10.1038/nmeth.2604

Faith, D. P. (1992). Conservation evaluation and phylogenetic diversity. Biol. Conservation 61, 1-10. doi: 10.1016/0006-3207(92)91201-3

Ferrenberg, S., Kane, J. M., and Mitton, J. B. (2014). Resin duct characteristics associated with tree resistance to bark beetles across lodgepole and limber pines. Oecologia 174, 1283-1292. doi: 10.1007/s00442-013-2841-2

Ferrenberg, S., and Mitton, J. B. (2014). Smooth bark surfaces can defend trees against insect attack: resurrecting a 'slippery' hypothesis. Funct. Ecol. 28, 837-845. doi: 10.1111/1365-2435.12228

Ferrenberg, S., O’Neill, S. P., Knelman, J. E., Todd, B., Duggan, S., Bradley, D., et al. (2013). Changes in assembly processes in soil bacterial communities following a wildfire disturbance. ISME J. 7, 1102-1111. doi: 10.1038/ismej. 2013.11

Fierer, N., and Jackson, R. (2006). The diversity and biogeography of soil bacterial communities. Proc. Natl. Acad. Sci. U.S.A. 103, 626-631. doi: 10.1073/pnas.0507535103

Finzi, A. C., Van Breemen, N., and Canham, C. D. (1998). Canopy tree-soil interactions within temperate forests: species effects on soil carbon and nitrogen. Ecol. Appl. 8, 440-446.

Fraterrigo, J. M., Balser, T. C., and Turner, M. G. (2006). Microbial community variation and its relationship with nitrogen mineralization in historically altered forests. Ecology 87, 570-579. doi: 10.1890/05-0638

Griffin, J. M., and Turner, M. G. (2012). Changes to the N cycle following bark beetle outbreaks in two contrasting conifer forest types. Oecologia 170, 551-565. doi: 10.1007/s00442-012-2323-y

Griffin, J. M., Turner, M. G., and Simard, M. (2011). Nitrogen cycling following mountain pine beetle disturbance in lodgepole pine forests of Greater Yellowstone. Forest Ecol. Manag. 261, 1077-1089. doi: 10.1016/j.foreco.2010.12.031

Griffiths, B. S., and Philippot, L. (2012). Insights into the resistance and resilience of the soil microbial community. FEMS Microbiol. Rev. 37, 112-129.

Gundersen, P., Schmidt, I. K., and Raulund-Rasmussen, K. (2006). Leaching of nitrate from temperate forests-Effects of air pollution and forest management. Environ. Rev. 14, 1-49. doi: 10.1139/a05-015

Hicke, J. A., Allen, C. D., Desai, A. R., Dietze, M. C., Hall, R. J., Hogg, E. H., et al. (2012). Effects of biotic disturbances on forest carbon cycling in the United States and Canada. Glob. Change Biol. 18, 7-34. doi: 10.1111/j.1365-2486.2011. 02543.x

Högberg, M. N., and Högberg, P. (2002). Extramatrical ectomycorrhizal mycelium contributes one-third of microbial biomass and produces together with associated roots, half the dissolved organic carbon in a forest soil. New Phytol. 154, 791-795. doi: 10.1046/j.1469-8137.2002.00417.x

Högberg, M. N., Högberg, P., and Myrold, D. D. (2007). Is microbial community composition in boreal forest soils determined by $\mathrm{pH}, \mathrm{C}$-to-N ratio, the trees, or all three? Oecologia 150, 590-601. doi: 10.1007/s00442-0060562-5

Kärvemo, S., Van Boeckel, T. P., Gilbert, M., Grégoire, J. C., and Schroeder, M. (2014). Large-scale risk mapping of an eruptive bark beetle-importance of forest susceptibility and beetle pressure. Forest Ecol. Manag. 318, 158-166. doi: 10.1016/j.foreco.2014.01.025 
Keville, M. P., Reed, S. C., and Cleveland, C. C. (2013). Nitrogen cycling responses to mountain pine beetle disturbance in a high elevation whitebark pine ecosystem. PLOS ONE 8:e65004. doi: 10.1371/journal.pone.0065004

Knelman, J. (2014a). Sequences: soil bacterial community structure remains stable over a five-year chronosequence of insect-induced tree mortality. figshare. doi: 10.6084/m9.figshare.1252207

Knelman, J. (2014b). Mapping file/metadata: soil bacterial community structure remains stable over a five-year chronosequence of insect-induced tree mortality. figshare doi: 10.6084/m9.figshare. 1252208

Knelman, J. E., Legg, T. M., O’Neill, S. P., Washenberger, C. L., Gonzalez, A., Cleveland, C. C., et al. (2012). Bacterial community structure and function change in association with colonizer plants during early primary succession in a glacier forefield. Soil Biol. Biochem. 46, 172-180. doi: 10.1016/j.soilbio.2011. 12.001

Kurz, W. A., Dymond, C. C., Stinson, G., Rampley, G. J., Neilson, E. T., Carroll, A. L., et al. (2008). Mountain pine beetle and forest carbon feedback to climate change. Nature 452, 987-990. doi: 10.1038/nature06777

Landesman, W. J., Nelson, D. M., and Fitzpatrick, M. C. (2014). Soil properties and tree species drive $B$-diversity of soil bacterial communities. Soil Biol. Biochem. 76 , 201-209. doi: 10.1016/j.soilbio.2014.05.025

Latifi, H., Schumann, B., Kautz, M., and Dech, S. (2014). Spatial characterization of bark beetle infestations by a multidate synergy of SPOT and Landsat imagery. Environ. Monit. Assess. 186, 441-456. doi: 10.1007/s10661-0133389-7

Lennon, J. T., and Jones, S. E. (2011). Microbial seed banks: ecological and evolutionary implications of dormancy. Nat. Rev. Microbiol. 9, 119-130. doi: 10.1038/nrmicro2504

Lozupone, C., and Knight, R. (2005). UniFrac: a new phylogenetic method for comparing microbial communities. Appl. Environ. Microbiol. 71, 8228-8235. doi: 10.1128/AEM.71.12.8228-8235.2005

McCune, B., and Mefford, M. J. (2011). PC-ORD. Multivariate Analysis of Ecological Data. Version 6.0. Gleneden Beach, OR: MjM Software.

Meddens, A. J., Hicke, J. A., and Ferguson, C. A. (2012). Spatiotemporal patterns of observed bark beetle-caused tree mortality in British Columbia and the western United States. Ecol. Appl. 22, 1876-1891. doi: 10.1890/111785.1

Mitton, J. B., and Ferrenberg, S. M. (2012). Mountain pine beetle develops an unprecedented summer generation in response to climate warming. Am. Nat. 179, E163-E171. doi: 10.1086/665007

Monson, R. K., Lipson, D. L., Burns, S. P., Turnipseed, A. A., Delany, A. C., Williams, M. A., et al. (2006). Winter forest soil respiration controlled by climate and microbial community composition. Nature 439, 711-714. doi: 10.1038/nature04555

Moore, D. J., Trahan, N. A., Wilkes, P., Quaife, T., Stephens, B. B., Elder, K., et al. (2013). Persistent reduced ecosystem respiration after insect disturbance in high elevation forests. Ecol. Lett. 16, 731-737. doi: 10.1111/ele. 12097

Morehouse, K., Johns, T., Kaye, J., and Kaye, M. (2008). Carbon and nitrogen cycling immediately following bark beetle outbreaks in southwestern ponderosa pine forests. Forest Ecol. Manag. 255, 2698-2708. doi: 10.1016/j.foreco.2008. 01.050

Mulvaney, R. L. (1996). "Nitrogen: Inorganic forms," in Methods of Soil Analysis, Part 3, SSSA Book Series 5, ed. D. L. Sparks (Madison, WI: SSSA),1123-1184.

Nemergut, D. R., Cleveland, C. C., Wieder, W. R., Washenberger, C. L., and Townsend, A. R. (2010). Plot-scale manipulations of organic matter inputs to soils correlate with shifts in microbial community composition in a lowland tropical rain forest. Soil Biol. Biochem. 42, 2153-2160. doi: 10.1016/j.soilbio.2010. 08.011

Nemergut, D. R., Schmidt, S. K., Fukami, T., O’Neill, S. P., Bilinski, T. M., Stanish, L. F., et al. (2013). Patterns and processes of microbial community assembly. Microbiol. Mol. Biol. Rev. 77, 342-356. doi: 10.1128/MMBR. 00051-12

Ofițeru, I. D., Lunn, M., Curtis, T. P., Wells, G. F., Criddle, C. S., Francis, C. A., et al. (2010). Combined niche and neutral effects in a microbial wastewater treatment community. Proc. Natl. Acad. Sci. U.S.A. 107, 15345-15350. doi: 10.1073/pnas.1000604107

Oksanen, J., Blanchet, F. G., Kindt, R., Legendre, P., Minchin, P. R., O’Hara, R. B., et al. (2013). Vegan: Community Ecology Package. R package version 2.0-10.
Philippot, L., Spor, A., Hénault, C., Bru, D., Bizouard, F., Jones, C. M., et al. (2013). Loss in microbial diversity affects nitrogen cycling in soil. ISME J. 7, 1609-1619. doi: 10.1038 /ismej.2013.34

R Development Core Team. (2011). R: A Language and Environment for Statistical Computing. Vienna: R Foundation for Statistical Computing.

Reed, H. E., and Martiny, J. B. (2007). Testing the functional significance of microbial composition in natural communities. FEMS Microbial. Ecol. 62, 161-170. doi: 10.1111/j.1574-6941.2007.00386.x

Reeder, J., and Knight, R. (2010). Rapidly denoising pyrosequencing amplicon reads by exploiting rank-abundance distributions. Nat. Methods 7, 668-669. doi: 10.1038/nmeth0910-668b

Rhoades, C. C., McCutchan, J. H., Cooper, L. A., Clow, D., Detmer, T., Briggs, J. S., et al. (2013). Biogeochemistry of beetle-killed forests: explaining a weak nitrate response. Proc. Natl. Acad. Sci. U.S.A. 110, 1756-1760. doi: 10.1073/pnas.1221029110

Schimel, J. P., and Gulledge, J. A. Y. (1998). Microbial community structure and global trace gases. Glob. Change Biol. 4, 745-758. doi: 10.1046/j.13652486.1998.00195. $\mathrm{x}$

Schimel, J. P., and Schaeffer, S. M. (2012). Microbial control over carbon cycling in soil. Front. Microbiol. 3:348. doi: 10.3389/fmicb.2012.00348

Shade, A., Peter, H., Allison, S. D., Baho, D. L., Berga, M., Bürgmann, H., et al. (2012). Fundamentals of microbial community resistance and resilience. Front. Microbiol. 3:417. doi: 10.3389/fmicb.2012.00417

Strickland, M. S., Lauber, C., Fierer, N., and Bradford, M. A. (2009). Testing the functional significance of microbial community composition. Ecology 90, 441451. doi: 10.1890/08-0296.1

Štursová, M., Šnajdr, J., Cajthaml, T., Bárta, J., Šantrůčková, H., and Baldrian, P. (2014). When the forest dies: the response of forest soil fungi to a bark beetleinduced tree dieback. ISME J. doi: 10.1038/ismej.2014.37

Thoms, C., Gattinger, A., Jacob, M., Thomas, F. M., and Gleixner, G. (2010). Direct and indirect effects of tree diversity drive soil microbial diversity in temperate deciduous forest. Soil Biol. Biochem. 42, 1558-1565. doi: 10.1016/j.soilbio.2010.05.030

Turner, M. G. (2010). Disturbance and landscape dynamics in a changing world. Ecology 91, 2833-2849. doi: 10.1890/10-0097.1

Turner, M. G., Smithwick, E. A. H., Metzger, K. L., Tinker, D. B., and Romme, W. H. (2007). Inorganic nitrogen availability following severe stand-replacing fire in the Greater Yellowstone Ecosystem. Proc. Natl. Acad. Sci. U.S.A. 104, 4782-4789. doi: 10.1073/pnas.0700180104

Ushio, M., Kitayama, K., and Balser, T. C. (2010). Tree species-mediated spatial patchiness of the composition of microbial community and physicochemical properties in the topsoils of a tropical montane forest. Soil Biol. Biochem. 42, 1588-1595. doi: 10.1016/j.soilbio.2010.05.035

Ushio, M., Wagai, R., Balser, T. C., and Kitayama, K. (2008). Variations in the soil microbial community composition of a tropical montane forest ecosystem: does tree species matter? Soil Biol. Biochem. 40, 2699-2702. doi: 10.1016/j.soilbio.2008.06.023

Van der Heijden, M. G., Bardgett, R. D., and Van Straalen, N. M. (2008). The unseen majority: soil microbes as drivers of plant diversity and productivity in terrestrial ecosystems. Ecol. Lett. 11, 296-310. doi: 10.1111/j.1461-0248.2007. 01139.x

Wang, Q., Garrity, G. M., Tiedje, J. M., and Cole, J. R. (2007). Naive Bayesian classifier for rapid assignment of rRNA sequences into the new bacterial taxonomy. Appl. Environ. Microbiol. 73, 5261-5267. doi: 10.1128/AEM. 00062-07

Wardle, D. A., Bardgett, R. D., Klironomos, J. N., Setälä, H., van der Putten, W. H., and Wall, D. H. (2004). Ecological linkages between aboveground and belowground biota. Science 304, 1629-1633. doi: 10.1126/science.1094875

Weber, P., and Bardgett, R. (2011). Influence of single trees on spatial and temporal patterns of belowground properties in native pine forest. Soil Biol. Biochem. 43, 1372-1378. doi: 10.1016/j.soilbio.2011. 03.015

Weintraub, M. N., Scott-Denton, L. E., Schmidt, S. K., and Monson, R. K. (2007). The effects of tree rhizodeposition on soil exoenzyme activity, dissolved organic carbon, and nutrient availability in a subalpine forest ecosystem. Oecologia 154, 327-338. doi: 10.1007/s00442-0070804-1 
Xiong, Y., D’Atri, J. J., Fu, S., Xia, H., and Seastedt, T. R. (2011). Rapid soil organic matter loss from forest dieback in a subalpine coniferous ecosystem. Soil Biol. Biochem. 43, 2450-2456. doi: 10.1016/j.soilbio.2011.08.013

Conflict of Interest Statement: The authors declare that the research was conducted in the absence of any commercial or financial relationships that could be construed as a potential conflict of interest. The Associate Editor, Jay Lennon, declares that, despite having collaborated with the author, Diana Nemergut, the review process was handled objectively and no conflict of interest exists.

Received: 05 August 2014; accepted: 20 November 2014; published online: 16 December 2014.
Citation: Ferrenberg S, Knelman JE, Jones JM, Beals SC, Bowman WD and Nemergut DR (2014) Soil bacterial community structure remains stable over a 5year chronosequence of insect-induced tree mortality. Front. Microbiol. 5:681. doi: 10.3389/fmicb.2014.00681

This article was submitted to Terrestrial Microbiology, a section of the journal Frontiers in Microbiology.

Copyright $\odot 2014$ Ferrenberg, Knelman, Jones, Beals, Bowman and Nemergut. This is an open-access article distributed under the terms of the Creative Commons Attribution License (CC BY). The use, distribution or reproduction in other forums is permitted, provided the original author(s) or licensor are credited and that the original publication in this journal is cited, in accordance with accepted academic practice. No use, distribution or reproduction is permitted which does not comply with these terms. 